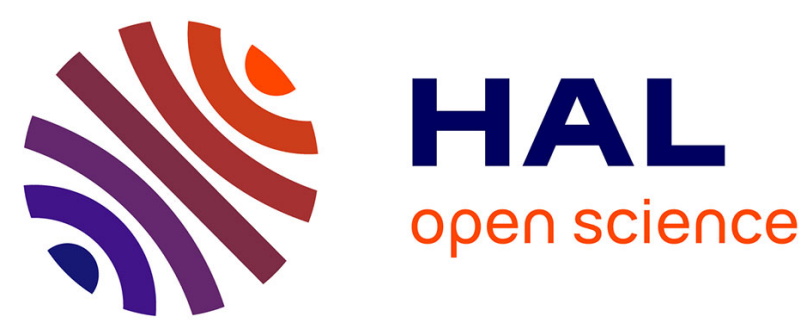

\title{
INFRARED LBIC SCAN MAPS APPLIED TO ALUMINIUM GETTERED MULTICRYSTALLINE SILICON WAFERS
}

\author{
J. Natoli, M. Pasquinelli, F. Floret, S. Martinuzzi
}

\section{- To cite this version:}

J. Natoli, M. Pasquinelli, F. Floret, S. Martinuzzi. INFRARED LBIC SCAN MAPS APPLIED TO ALUMINIUM GETTERED MULTICRYSTALLINE SILICON WAFERS. Journal de Physique IV Proceedings, 1991, 01 (C6), pp.C6-237-C6-238. 10.1051/jp4:1991637 . jpa-00250723

HAL Id: jpa-00250723

https://hal.science/jpa-00250723

Submitted on 1 Jan 1991

HAL is a multi-disciplinary open access archive for the deposit and dissemination of scientific research documents, whether they are published or not. The documents may come from teaching and research institutions in France or abroad, or from public or private research centers.
L'archive ouverte pluridisciplinaire HAL, est destinée au dépôt et à la diffusion de documents scientifiques de niveau recherche, publiés ou non, émanant des établissements d'enseignement et de recherche français ou étrangers, des laboratoires publics ou privés. 


\title{
INFRARED LBIC SCAN MAPS APPLIED TO ALUMINIUM GETTERED MULTICRYSTALLINE SILICON WAFERS
}

\author{
J.Y. NATOLI, M. PASQUINELLI, F. FLORET and S. MARTINUZZI \\ Laboratoire de Photoélectricité des Semiconducteurs, Case 231, Faculté des Sciences et \\ Techniques de Marseille, F-13397 Marseille Cedex 13, France
}

The use of thin wafers $(\mathrm{d}<200 \mu \mathrm{m})$ of improved $P$ type multicrystalline wafers to make solar cells call for the use of a back surface field effect realized at low temperatures $\left(<800^{\circ} \mathrm{C}\right)$.

Diffusion of aluminium could be successfully used because $\mathrm{Al}$ is an acceptor in silicon, $\mathrm{Al}$ diffuses more rapidly than boron and Al layers are used as ohmic contacts. In addition it is known that the annealing of an Al-Si interface at temperatures between 400 and $800^{\circ} \mathrm{C}$ improves the minority carrier diffusion lengths $L_{n}$. It is interesting to verify if this annealing reduces the recombination strength of grain boundaries (GBs) or of extended intragrain defects like dislocations and subgrain boundaries. Near infrared LBIC scan mapping is a suited technique (fig.1)

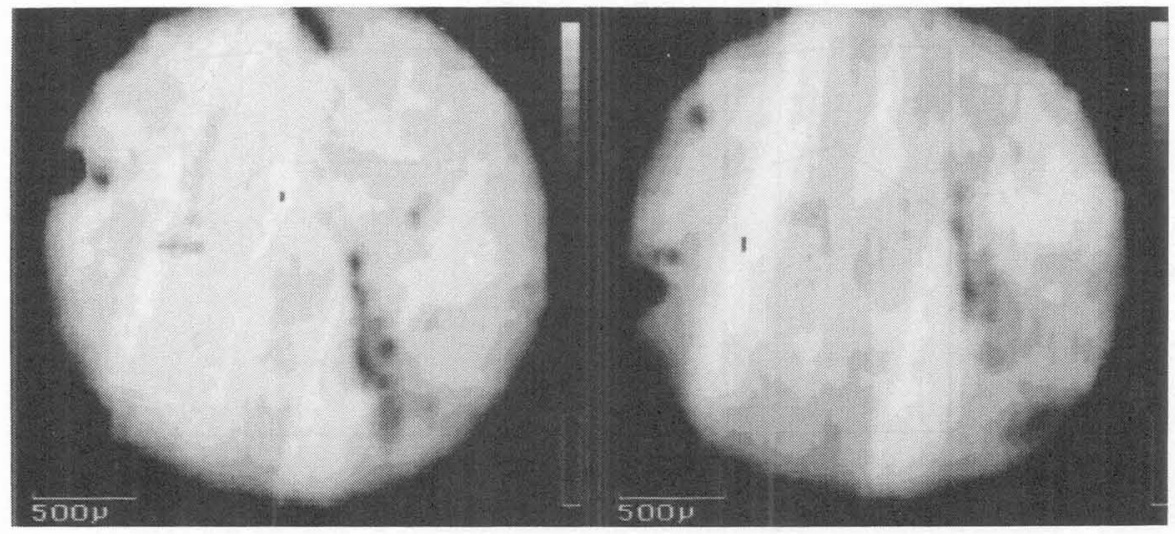

Fig.1. LBIC scan maps ( $\lambda=940 \mathrm{~nm}$ ) for a gettered material (left) and a gettered and Aluminium treatment sample (right)

$P$ type Polix wafers cut adjacently in the same ingot have been studied. They presented the same distribution and nature of defects. Series of matched samples $\left(2 \times 2 \mathrm{~cm}^{2}\right)$ were cut out of the wafers and submitted to phosphorus diffusion by the two surfaces, at $850^{\circ} \mathrm{C}$ for 12 and $240 \mathrm{mn}$. The longer diffused samples were called gettered, while the $12 \mathrm{mn}$ were labeled standard.

$\mathrm{N}^{+} \mathrm{P}$ mesa diodes were revealed on one face and the other face was chemically etched and 
then covered by a thick $(1 \mu \mathrm{m})$ Al layer. Then the structure was annealed at $800^{\circ} \mathrm{C}$ for $30 \mathrm{mn}$ in argon and at $450^{\circ} \mathrm{C}$ for $30 \mathrm{mn}$ to get an ohmic contact only. Effective diffusion lengths $\mathrm{L}_{n}$ have been determined from the spectral variation of the photocurrent in the near infrared. It was found that $L_{n}$ increases drastically in the gettered samples and reaches at least the sample thickness after the annealing. LBIC scan maps at $\lambda=940 \mathrm{~nm}$ indicate that the recombination strength of GBs is reduced while the photocurrent in the grains, specially in dislocation containing regions, are enhanced (fig.1). The standard samples are less improved (fig.2), than the gettered wafers (fig.3)).

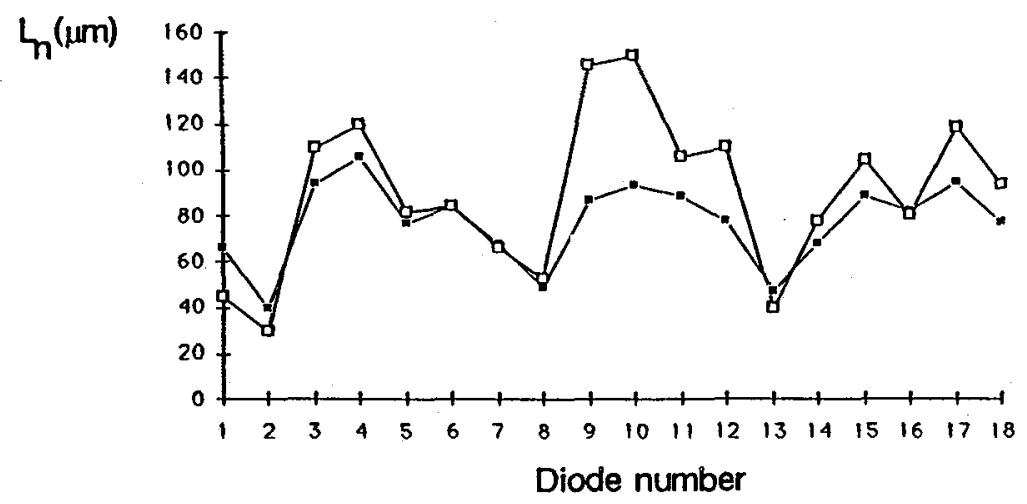

Fig.2. Diffusion length variations after annealing of standard samples for $30 \mathrm{mn}$ $\left(=450^{\circ} \mathrm{C}, \square 800^{\circ} \mathrm{C}\right)$.

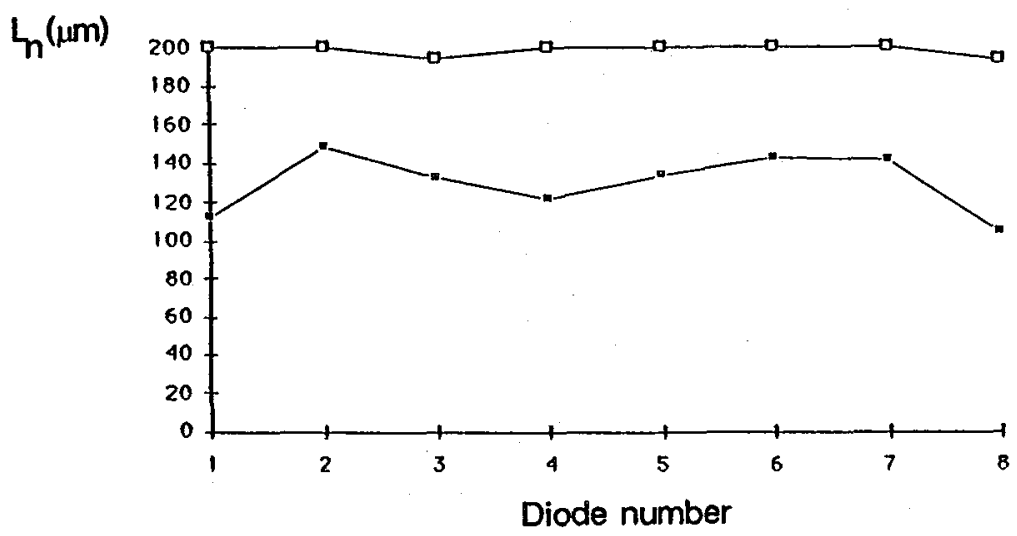

Fig.3. Diffusion length variations after annealing of gettered samples for $30 \mathrm{mn}$ $\left(-450^{\circ} \mathrm{C}, \square 800^{\circ} \mathrm{C}\right)$.

It is concluded that the improvement of $L_{n}$ is due to an aluminium intragrain defects interaction which neutralizes recombination centers, or to a backside gettering effect of impurities which cannot be removed by the phosphorus gettering. This external gettering is able to remove fast diffusers and impurity atoms which diffuse more rapidly than silicon self interstitials and not other impurity atoms like oxygen.

However the existence of a back surface field effect is not precluded in the gettered samples in which the diffusion lengths reach $150 \mu \mathrm{m}$ (so around 2/3 of the thickness). 